\title{
POLA WILLINGNES TO PAY (WTP) DAN FAKTOR - FAKTOR YANG \\ MEMPENGARUHI TERHADAP PILIHAN SAYUR ORGANIK DAN ANORGANIK MASYARAKAT KOTA MALANG
}

\author{
Umi Rofiatin dan Hanif Fikri Bariska \\ Dosen Fakultas Pertanian \\ Universitas Tribhuwana Tunggadewi
}

\begin{abstract}
ABSTRAK
Berdasarkan data World Health Organization (WHO) tahun 2011, penyebab kematian di negara-negara berkembang sebesar $60 \%$ diakibatkan oleh penyakit tidak menular. Siro et al (2008) menyampaikan bahwa masyarakat mulai percaya bahwa makanan yang mereka konsumsi akan memberikan kontribusi terhadap kesehatan. Salah satunya adalah konsumsi sayur organik dan anorganik. Mempelajari pola pengambilan keputusan konsumen dalam pemilihan produk melalui analisa Willingnes to Pay ( WTP) atas sayur organik dan sayur anorganik dan mengetahui faktor kunci merupakan salah satu upaya mengetahui pola konsumsi dari masyarakat atas komoditi sayuran. Mengetahui dengan tepat pola WTP dan faktor kuncinya memungkinkan kita dapat mengetahui strategi yang sesuai untuk memberikan konstribusi pada pemenuhan pola pangan harapan masyarakat.

Hasil penelitian mengatakan bahwa karakteristik responden dalam penelitian yang mempengaruhi adalah jenis kelamin responden yaitu perempuan karena perempuan yang sudah berumah tangga merupakan faktor penentu pembuat keputusan dalam hal pemenuhan kebutuhan rumah tangga. Faktor yang mempengaruhi dari kesediaan konsumen dalam membayar sayur organik adalah usia, pendidikan,pendapatan, kualitas produk dan dampak kesehatan. Faktor yang mempengaruhi kesediaan konsumen dalam membayar sayur anorganik adalah usia, pekerjaan, pendapatan, harga, kualitas produk, dampak kesehatan.
\end{abstract}

\section{Kata kunci: kesediaan membayar, organik dan anorganik, masyarakat, pola konsumsi}

\section{PENDAHULUAN}

Salah satu target kementrian

pertanian tahun $2010-2014$ adalah peningkatan konsumsi umbi - umbian, pangan hewani, buah-buahan dan sayuran. Selain itu juga diupayakan tercapainya pola konsumsi pangan beragam, bergizi, seimbang dan aman yang tercermin oleh meningkatnya skor pola pangan Harapan (PPH) dari 86,4 pada tahun 2010 menjadi 93,3 pada tahun 2014. Pilihan akan kesediaan membayar sayur organik dan sayur anorganik sebagai produk pangan yang diharapkan akan menjadi alternatif diversifikasi pangan. Dengan mengetahui mengestimasi dan menganalisa faktor faktor kunci yang menjadikan kesediaan konsumen untuk menentukan pilihan akan konsumsi sayur organik atau sayur anorganik, diharapkan pemerintah dapat menentukan pola perilaku konsumen sebagai salah satu trend yang nantinya dapat mengambil kebijakan dengan tepat didalam hal diversifikasi pangan.

Tujuan penelitian yang penulis lakukan adalah untuk menganalisa karakteristik konsumen sayur organik dan sayur anorganik, Mengestimasi nilai 
kesediaan membayar (WTP) terhadap pilihan sayur organik dan sayur anorganik dan menganalisis faktor -faktor apa saja yang mempengaruhi nilai kesediaan membayar ( WTP) terhadap pilihan sayur organik dan sayur.

\section{TINJAUAN PUSTAKA}

\section{Wilingness To Pay (WTP)}

Secara umum, wilingness to pay atau kemauan/keinginan untuk membayar didefinisikan sebagai jumlah yang dapat dibayarkan seorang konsumen untuk memperoleh suatu barang atau jasa. Wilingness to pay adalah harga maksimum dari suatu barang yang ingin dibeli oleh konsumen pada waktu tertentu. Wilingness to pay merupakan kesanggupan seorang konsumen untuk membeli suatu barang. Wilingness to pay itu sebenarnya adalah harga pada tingkat konsumen yang merefleksikan nilai barang atau jasa dan pengorbanan untuk memperolehnya. Disisi lain, Wilingness to pay ditujukan untuk mengetahui daya beli konsumen berdasarkan persepsi konsumen. Untuk memahami konsep Wilingness to pay konsumen terhadap suatu barang atau jasa harus dimulai dari konsep utilitas, yaitu manfaat atau kepuasan karena mengkonsumsi barang atau jasa pada waktu tertentu. Setiap individu ataupun rumah tangga selalu berusaha untuk memaksimumkan utilitasnya dengan pendapatan tertentu, dan ini akan menentukan jumlah permintaan barang atau jasa yang akan dikonsumsi. Permintaan diartikan sebagai jumlah barang atau jasa yang mau atau ingin dibeli atau dibayar (willingness to buy or willingness to pay) oleh konsumen pada harga tertentu dan waktu tertentu. Utilitas yang akan didapat oleh seorang konsumen memiliki kaitan dengan harga yang dibayarkan yang dapat diukur dengan Wilingness to pay. Sejumlah uang yang ingin dibayarkan oleh konsumen akan menunjukkan indikator utilitas yang diperoleh dari barang tersebut. Konsep pengukuran utilitas dengan menggunakan WTP telah banyak dilakukan terutama untuk barang/jasa publik (public goods or public service) yang tidak diperdagangkan (non-traded or non-marketed). Alasan penggunaan Wilingness to pay dalam barang atau jasa publik adalah karena harga atau nilai pasarnya gagal direfleksikan kepada masyarakat atau konsumen ataupun karena keabsenan transaksi-transaksi pasar (John C, 2009 ).

Untuk suatu produk atau jasa tertentu,penetapan harga atau tarifnya harus disesuaikan dengan permintaan masyarakat. Salah satu metode untuk mengukur keinginan / permintaan masyarakat adalah dengan survey WTP (willingness to pay). Survei WTP dilakukan dengan mendata tingkat kemauan berbelanja pada harga 
tertentu untuk suatu produk atau jasa tertentu. Studi tentang WTP (willingness to pay) merupakan survei rumah tangga yang cukupsederhana, dimana anggota keluarga diberikan daftar pertanyaan terstruktur yang dirancang untuk mengukur jumlah pembayaran maksimum yang bersedia dibayar (willingness to pay) untuk suatu barang atau jasa tertentu. WTP didefinisikan sebagai suatu jumlah maksimum dari uang yang mungkin dibayarkan oleh seseorangsesuai dengan perubahan kegunaan / manfaat yang dirasakan. Studi WTP disebut juga sebagai penelitian "contingent valuation" karena responden ditanya tentang apa yang akan responden lakukan dalam suatu keadaan yang dihipotesakan/ digambarkan kepadanya. WTP harga dapat digunakan untuk mengestimasi pendapatan yang paling optimal dari besarnya jumlah uang yang mau dibayarkan berdasarkan data frekuensi kumulatif atas pembayaran maksimum yang willingness to pay untuk produk/jasa tertentu. Dengan membuat plot antara frekwensi kumulatif WTP dengan jumlah pendapatan, akan diketahui pendapatan maksimal yang akan diperoleh (Dyah jurnal penentuan harga sewarumah susun bedasarkan analisa WTP (Wilingness to pay) di Kecamatan Sidoarjo)

Berdasarkan analisa WTP antara konsumen dengan produk sayur organik maka diketahui bahwa berdasarkan analisis
SEM faktor - faktor yang mempengaruhi terhadap WTP adalah analisis SEM adalah : sikap (kepercayaan terhadap klaim sayuran organik, perhatian terhadap kesehatan dan lingkungan, dan persepsi terhadap atribut sayuran organik) dan tingkat hambatan pembelian konsumen (persepsi biaya) (Priambodo Najib, 2014). Hasil penelitian Ameriana, 2006 juga mengatakan bahwa faktor yang mempengaruhi kesediaan konsumen untuk membayar premium tomat dipengaruhi oleh jumlah anggota keluarga, pengeluaran keluarga, kepedulian konsumen serta keyakinan konsumen terhadap produk.

\section{METODE PENELITIAN}

Populasi dalam penelitian ini adalah masyarakat kota Malang. Pengambilan sampel responden penelitian dilakukan dengan menggunakan purposive sampling. Sampel responden dibagi lagi menjadi beberapa bagian dengan cara quota sampling. Sampel responden dibagi menjadi 6 lokasi, yaitu 3 lokasi supermarket (superindo, Hypermart dan giant) dan 3 lokasi pasar tradisional (UPT Pasar Oro Oro Dowo (Pasar Mergan dan Pasar Oro Oro Dowo) dan pasar Blimbing) yang menjual sayur organik dan sayur anorganik dengan masing masing lokasi berjumlah 50 responden. Data yang dikumpulkan dianalisa dengan menggunakan teknik regresi linier Berganda dengan menggunakan SPSS 
$\mathrm{Y}=\beta 0+\beta 1 \chi 1+\beta 2 \chi^{2}+\beta 3 \chi^{3}+\beta \mathrm{n} \chi \mathrm{n} \quad+\mathrm{U}$

Untuk mengetahui hasil tanggapan responden terhadap variabel-veriabel penelitian maka digunakan skala pengukuran (skala likert) yang di gunakan untuk mengukur sikap, pendapat, persepsi, seseorang atau kelompok tertentu. Dalam memberikan penilaian perlu adanya pemberian skor atau interval dengan skala 1-5. Sedangkan untuk mengetahui pengukuran dan interpretasi data, maka data interval dibagi menjadi 5 (lima) skor interval sebagai berikut :

SANGAT TIDAK SETUJU

TIDAK SETUJU

CUKUP SETUJU

SETUJU

SANGAT SETUJU

Dengan variabel:

y : Kesediaan Konsumen untuk membayar sayur organik atau sayur anorganik

$\mathrm{x} 1$ : Usia (umur responden dalam tahun)

x2: Jumlah keluarga (jumlah orang dalam keluarga yang secara konstan menjadi tanggungan kepala rumah tangga)

x3:Pekerjaan (profesi responden)

$\mathrm{x} 4$ :Pendidikan (tingkat pendidikan responden dalam tahun duduk dibangku sekolah)

x5: Pendapatan responden

x6: Harga produk

$\mathrm{x} 7$ : Kualitas produk

x8: dampak bagi kesehatan

\section{HASIL DAN PEMBAHASAN}

Responden pada penelitian ini sebagian besar berjenis kelamin Wanita yaitu 225 orang (75\%). Hal ini dikarenakan terdapat kecenderungan terhadap peran perempuan dalam proses pengambilan keputusan rumah tangga terkait dengan kesediaan dalam melakukan pembelian kebutuhan pokok dalam komoditi sayur organik maupun sayur anorganik.

\section{Karakteristik Responden}

Karaktateristik $\underline{=}_{1}$ responden penelitian ini meliputi (1êtang 2 usia responden pada penelitian ${ }_{(\mathrm{S})}^{(\mathrm{CS})_{\text {Ini }}=}=$ ? $_{\text {paling }}$ tinggi adalah

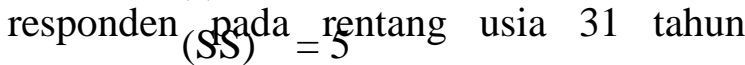
sampai dengan usia 41 tahun sebanyak 132 orang atau $44 \%$. Sedangkan usia 42 tahun sampai 52 tahun terdapat 99 orang atau berkisar $33 \%$. hal ini terlihat bahwa usia 31 tahun sampai dengan 41 tahun, merupakan usia yang cukup matang dalam mengambl keputusan dalam pembelian sayur organik maupun anorganik

Jumlah keluarga responden yang dimiliki 2 sampai 3 orang terdapat 131 orang 43,67\%, jumlah keluarga 4 sampai 5 orang yang dimiliki responden terdapat 164 orang atau 54,67 \%, sedangkan jumlah anggota keluarga yang dimiliki responden dengan jumlah diatas 6 orang hanya 5 orang atau $1,67 \%$. 
Menurut tingkat pendidikan, dari 181 orang sebagian besar berpendidikan Sarjana yaitu sebesar 60,3 persen, responden dengan tingkat pendidikan SLTP 5 orang atau $1,67 \%$, sedangkan 36 orang atau 12 persen dengan tingkat pendidikan SLTA, dan 3 orang dengan pendidikan SD 3 orang atau 1 persen.

Berdasarkan tingkat rata - rata pendapatan responden tiap bulan, kebanyakan responden mempunyai pendapatan sebesar Rp. >3.000.001 yaitu 215 orang atau 71,67 persen dan rata - rata pendapatan terendah pada pendapatan $\mathrm{Rp}$. $<1.000 .000$ yaitu 17 orang responden atau $5,67 \%$. Pendapatan rata - rata $\mathrm{Rp}$. 1.000.001,- - 2.000.000 sebanyak 33 orang atau 11 persen, sebaran responden dengan pendapatan Rp. 2.000.001,- - 3.000.000 35 orang atau 11,67 persen. Dan tidak terdapat pada masyarakat yang mempunyai pendapatan Rp dibawah 250.000 .

\section{ANALISIS KESEDIAAN KONSUMEN DALAM KEPUTUSAN PEMBELIAN PADA KOMODITI SAYUR ORGANIK}

Tabel 1. Sebaran Keputusan Pembelian Konsumen Sayur Organik

\begin{tabular}{|c|l|c|c|}
\hline No & \multicolumn{1}{|c|}{ Keterangan } & $\begin{array}{c}\text { Jumlah } \\
\text { Responden }(\mathrm{n})\end{array}$ & $\begin{array}{c}\text { Persentase } \\
(\%)\end{array}$ \\
\hline 1 & Bersedia membeli & 231 & 77 \\
\hline 2 & Tidak bersedia membeli & 69 & 33 \\
\hline
\end{tabular}

Alasan responden memutuskan untuk membeli sayur organik adalah karena menginginkan dampak yang baik terhadap kesehatan tubuh mereka, selain itu karena pengobatan terhadap suatu penyakit yang diderita oleh responden, sayur organik mempunyai kualitas yang lebih bagus daripada sayur anorganik. Sedangkan responden yang tidak bersedia membayar untuk memutuskan membeli sayur organik memberikan alasan bahwa harga sayur organik mahal, tidak bisa membedakan sayur organik atau anorganik), sayur organik tidak selalu tersedia pada lokasi pembelian. Jenis sayur organik terbatas.
Faktor - Faktor yang Mempengaruhi Kesediaan Konsumen dalam Keputusan Pembelian Sayur Organik

Hasil penelitian menunjukkan bahwa usia responden, jumlah keluarga dan pekerjaan, tidak berpengaruh terhadap keputusan pembelian konsumen pada komoditi sayur organik, sedangkan faktor - faktor yang mempengaruhi dalam kesediaan membayar antara lain : Pendidikan berpengaruh positif terhadap keputusan pembelian sayur organik. Semakin tinggi jenjang pendidikan seseorang akan menambah luas pengetahuan seseorang tentang manfaat 
yang ditimbulkan pada saat mengkonsumsi sayur organik secara rutin. Sehingga, dengan bertambahnya pengetahuan tersebut dapat mempengaruhi keputusan dalam pembelian sayur organik. Pendapatan berpengaruh dengan pendapatan yang tinggi, seseorang dapat memiliki peluang lebih besar untuk mengambil keputusan terhadap pembayaran sayur organik. Harga sayur organik memiliki pengaruh negatif, hal ini terlihat pada saat harga sayur organik naik maka keputusan konsumen dalam membayar sayur turun, atau mereka tetap akan membeli tetapi kuantitas sayur dikurangi. Kualitas produk mempunyai pengaruh yang positif, semakin bagus kualitas produk yang ditampilkan maka keputusan pembelian semakin meningkat.
Kualitas produk yang dimaksud disini adalah kemasan sayur organik pada saat dibeli, kondisi fisik dari sayur organik segar, warna bagus,terdapat kejelasan kualifikasi sayur. Dampak kesehatan mempunyai pengaruh positif, hal ini dikarenakan masyarakat menyadari betapa pentingnya pola hidup sehat yang sangat berpengaruh pada pola konsumsi yang mereka makan. Dengan mengkonsumsi sayur organik, baik brokoli, kangkung, bayam merah dan lain-lain akan berdampak pada kesehatan tubuh. Sayur organik tidak mengandung bahan-bahan yang berbahaya dan tidak mengandung zat-zat kimia, yang berasal dari pupuk maupun pestisida yang berbahaya bagi tubuh.

Tabel 2. Faktor-faktor yang Mempengaruhi Kesediaan Konsumen dalam Keputusan Pembelian Sayur Organik

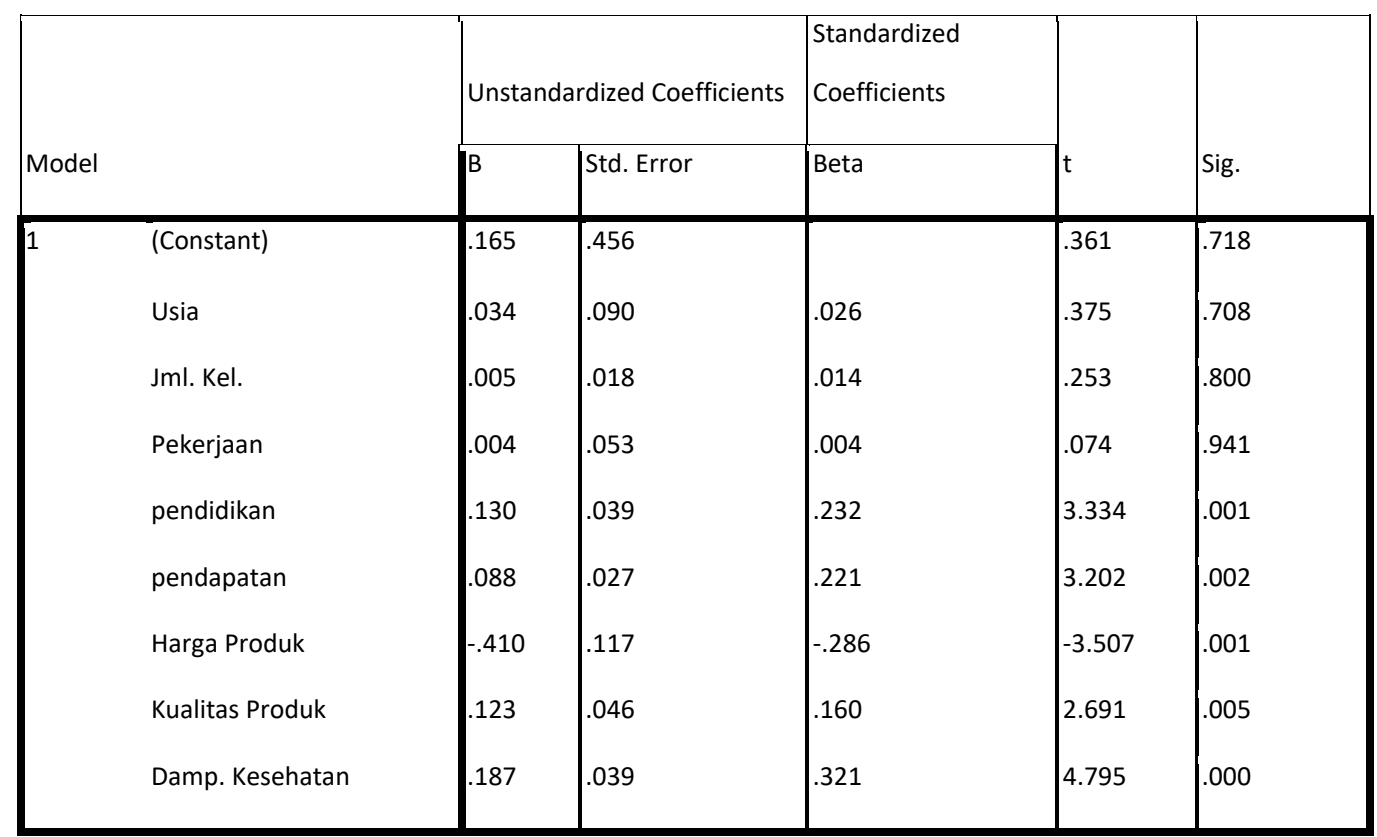


Tabel. 3. Distribusi Pilihan Sayur Organik yang Sering Dibeli Konsumen Beserta Harga

\begin{tabular}{|l|l|l|l|}
\hline No & \multicolumn{1}{|c|}{ Jenis Sayuran } & Harga sayur organik/kg & Harga Sayur anorganik/kg \\
\hline 1 & Kol & 21.900 & 12.000 \\
\hline 2. & Brokoli & 59.900 & 15.000 \\
\hline 3. & Wortel & 34.900 & 10.000 \\
\hline 4. & Selada & 30.000 & 8.000 \\
\hline 5. & Pakchoy & 30.000 & 7500 \\
\hline 6. & Kangkung (ikat) & 13.500 & 4000 \\
\hline 7. & Caisim (ikat) & 12.950 & 8000 \\
\hline 8. & Bayam Merah (ikat) & 10.900 & - \\
\hline
\end{tabular}

\section{Analisis Kesediaan Konsumen Dalam Membeli Sayur Anorganik}

Hasil penelitian menunjukkan bahwa kesediaan responden dalam melakukan pembelian pada komoditi sayur anorganik sebanyak 212 orang atau $70 \%$ dan yang tidak bersedia membayar pada pembelian komoditi sayur organik sebesar 88 orang atau $33 \%$. Seperti yang terlihat pada tabel 4 dibawah ini.

Tabel 4. Kesediaan Responden dalam Membeli Komoditi Sayur Anorganik

\begin{tabular}{|l|l|l|l|}
\hline No & \multicolumn{1}{|c|}{ Keterangan } & Jumlah Responden (n) & Persentase (\%) \\
\hline 1 & Bersedia membeli & 212 & 70,67 \\
\hline 2 & Tidak bersedia membeli & 88 & 29,33 \\
\hline
\end{tabular}

Alasan responden bersedia membeli sayur anorganik adalah karena tidak bisa merasakan dampak yang ditimbulkan jika mengkonsumsi sayur anorganik, sayur anorganik sama saja dengan sayur organik, harga sayur anorganik lebih murah dari

Faktor-Faktor yang Mempengaruhi Kesediaan Konsumen dalam Membeli Sayur Anorganik pada sayur organik, jumlah keluarga banyak. Sedangkan yang tidak bersedia membeli sayur anorganik adalah karena responden merasakan dampak kesehatan bagi tubuhnya karena suatu penyakit yang diderita.

Tabel 5. Hasil Analisa Faktor - Faktor yang Mempengaruhi

Kesediaan Konsumen dalam Membeli Sayur Anorganik

\begin{tabular}{|c|c|c|c|c|c|c|}
\hline \multirow{2}{*}{\multicolumn{2}{|c|}{ Model }} & \multicolumn{2}{|c|}{ Unstandardized Coefficients } & \multirow{2}{*}{\begin{tabular}{|l} 
Standardized \\
Coefficients \\
Beta \\
\end{tabular}} & \multirow[b]{2}{*}{$\mathrm{t}$} & \multirow[b]{2}{*}{ Sig. } \\
\hline & & $B$ & Std. Error & & & \\
\hline \multirow[t]{3}{*}{1} & (Constant) & 1.435 & .427 & & 3.365 & .001 \\
\hline & Usia & .410 & .117 & .286 & 3.507 & .001 \\
\hline & Jml. Kel. & .001 & .020 & .004 & $\mid .067$ & .947 \\
\hline
\end{tabular}




\begin{tabular}{|l|l|l|l|l|l|}
\hline Work & -.080 & .057 & -.079 & -1.387 & .166 \\
Pddk & .035 & .039 & .056 & .889 & .375 \\
Pdpt & -.096 & .029 & -.217 & -3.339 & .001 \\
harga an.organik & -.095 & .061 & -.141 & -1.541 & .125 \\
kualitas an.organik & -.076 & .066 & -.103 & -1.154 & .249 \\
dampak kes. & -.142 & .082 & -.138 & -1.720 & .086 \\
\hline
\end{tabular}

Berdasarkan hasil analisa diatas, variabel yang dapat mempengaruhi keputusan konsumen dalam membeli sayur anorganik adalah usia responden dan pendapatan. Semakin bertambah usia responden keinginan untuk membeli sayuran anorganik semakin besar. Hal ini karena sistem metabolisme tubuh usia tua (31 tahun keatas), berbeda dengan sistem metabolisme usia dibawah 31 tahun. Pada usia tersebut konsumen sudah mulai berfikir untuk menjaga kesehatan dengan merubah pola konsumsi dengan salah satunya memperbanyak mengkonsumsi sayur. Keputusan pembelian pada sayur anorganik karena alasan mudah didapat bisa dipasar tradisional, maupun pedagang keliling, dengan harga yang masih terjangkau dengan jenis lebih bervariatif. Pendapatan berpengaruh negatif, sehingga semakin tinggi pendapatan maka kesediaan untuk membayar pada sayur anorganik menurun. Karena konsumen dapat melakukan keleluasaan dalam pengambilan keputusan pembelian sayur anorganik. Dengan semakin meningkatnya pendapatan maka konsumen akan lebih mudah dalam mengambil keputusan dalam pembelian.
Apakah berganti dengan membeli sayur organik dengan konsekuensi harga yang lebih mahal, karena mengetahui dampak yang ditimbulkan jika mengkonsumsi sayur anorganik secara rutin.

\section{KESIMPULAN}

1. Karakteristik konsumen dalam melakukan kesediaan pembayaran terhadap sayur organik dan sayur anorganik mayoritas konsumen berjenis kelamin perempuan yang mempunyai rentang usia antara 31-41 tahun sebesar 44\%, dengan tingkat pendidikan tertinggi sarjana sebesar $60,3 \%$.

2. Kesediaan membayar konsumen pada sayur organik dan sayur anorganik berbeda - beda didasarkan pada jenis sayur yang dibeli.

3. Faktor-faktor yang mempengaruhi kesediaan konsumen dalam membeli sayur organik meliputi:pendidikan mempunyai pengaruh positif, pendapatan mempunyai pengaruh positif, harga produk mempunyai pengaruh negatif, kualitas produk mempunyai pengaruh positif dan 
dampak kesehatan mempunyai pengaruh positif terhadap kesediaan konsumen dalam membeli sayur organik. Sedangkan faktor-faktor yang mempengaruhi kesediaan konsumen dalam membeli sayur anorganik adalah: usia dan pendapatan. Usia berpengaruh positif terhadap keputusan pembelian sedang pendapatan berpengaruh negatif terhadap keputusan pembelian sayur anorganik.

\section{DAFTAR PUSTAKA}

Ali, Saadi. 2009. "Analysis of Factors Affecting Agricultural Organic Products Difusion Among Consumers: Perception of Extension Workers" World Applied Sciences Journal Vol 6 Number 3 Pages 331-338. Iran.

Annonymous. 2010. Rencana Strategis Kementrian Pertanian 2010-2014. Jakarta: Kementrian Pertanian Republik Indonesia.

Agustina, Shinta. 2011. Manajemen Pemasaran. Malang: Fakultas Pertanian Universitas Brawijaya.
Ameriana M. 2006. Kesediaan Konsumen Membayar Premium untuk Tomat Aman Residu Pestisida.

Dyah, Purnamasari dan Retno Indryani. 2011. Penentuan Harga Sewa Rumah Susun Berdasarkan Analisa Wtp (Willingness To Pay) Di Kecamatan Sidoarjo. Surabaya: Magister Manajemen Aset FTSP ITS.

John C. Whitehead, Thomas J.Hoban, and William B.Clifford. 2009. "Willingnes to Pay For Agricultural Research and Extension Programs" Journal of Agricultural and Applied Economics 33.1 :91-101

Priambodo, Ajib. 2014. "Analisis Kesediaan Membayar (Willingness to Pay) Sayuran Organik dan Faktor-Faktor yang Mempengaruhinya di Bogor" Jurnal Manajemen dan Organisasi Vol V, No 1, April 2014

Ratih Fadlilah Awaliyah, 2010. "Analisis Pengaruh Persepsi Konsumen dan Bonus dalam Kemasan Terhadap Keputusan Pembelian" (Thesis). Jakarta: Fakultas Ekonomi dan Bisnis. Universitas Islam Negeri Syarif Hidayatullah.

Sirieix et al, 2008. Consumer Perception of Vegetabkes Resulting from Conventional Field Orgreenhouse Agricultural Methods. Unite Mixtede Recherche Marches Organisations Institutions Strategies d'Acteurs. 